\title{
Role of boron addition on the consolidation and properties of steel composites prepared by SPS
}

\author{
IWONA SULIMA (1) \\ Institute of Technology, Pedagogical University of Krakow, Podchorazych 2 St., 30-084 Krakow, Poland
}

MS received 29 January 2015; accepted 6 July 2015

\begin{abstract}
Composites reinforced with 8 vol\% $\mathrm{TiB}_{2}$ were subjected to the consolidation process by spark plasma sintering (SPS). The results show that the addition of boron (1 vol\%) introduced to the steel matrix has a significant effect on the composite microstructure, as well as physical, mechanical and tribological properties. The full density of $97-99 \%$ was obtained in the composites sintered at a temperature of $1100^{\circ} \mathrm{C}$. The steel-8\% $\mathrm{TiB}_{2}-1 \% \mathrm{~B}$ composite sintered at $1100^{\circ} \mathrm{C}$ for $30 \mathrm{~min}$ was characterized by the highest microhardness $(465 \mathrm{HVO} .3)$ and Young's modulus (229 GPa), combined with the best compressive strength (1150 MPa) and abrasive wear resistance $(\mu=0.25$ and $W_{V \text { (disc) }}=207.78 \times 10^{-6} \mathrm{~mm}^{3} \mathrm{~N}^{-1} \mathrm{~m}^{-1}$ ). The microstructure and chemical composition were examined by scanning electron microscopy and transmission electron microscopy. The examinations have revealed the presence of numerous fine complex borides in the microstructure of the steel-8\% $\mathrm{TiB}_{2}$ and steel-8\% $\mathrm{TiB}_{2}-1 \% \mathrm{~B}_{\text {composites. }}$
\end{abstract}

Keywords. Metal matrix composite; spark plasma sintering; boron; austenitic steel; sintering aid.

\section{Introduction}

Austenitic steels are characterized by a unique combination of high mechanical properties and very high resistance to corrosion and oxidation, and for that reason they are considered as one of the leaders in the most important group of metal-based engineering materials. However, low abrasion resistance limits the use of these steels in some specific areas of industry where the wear of material is a key issue. ${ }^{1}$ The introduction of hard ceramic particles to austenitic steel seems to be a reasonable way to improve the tribological properties, as well as the strength and stiffness. ${ }^{2,3}$ Ceramic materials regarded as a possible reinforcing phase for steel- or iron-based composites include carbides $\left(\mathrm{SiC}, \mathrm{TiC}, \mathrm{Cr}_{3} \mathrm{C}_{2}, \mathrm{WC}, \mathrm{VC}\right),{ }^{4,5}$ oxides $\left(\mathrm{Al}_{2} \mathrm{O}_{3}, \mathrm{ZrO}_{2}, \mathrm{Y}_{2} \mathrm{O}_{3}\right)^{6,7}$ and borides $\left(\mathrm{TiB}_{2}, \mathrm{CrB}_{2}\right)^{8}{ }^{8,9}$

Powder metallurgy offers attractive sintering methods for various materials that help in the reduction of manufacturing costs and achieve a very high yield of $95 \% .^{10,11}$ Spark plasma sintering (SPS) is an intensively developing technique for powder sintering. The SPS process is performed using electric discharges of high intensity but low voltage. At the same time, the powder is exposed to the effect of pressure applied between the punches. The theory describing the sintering mechanism occurring between the particles during SPS divides the process into the following steps: (1) activation and cleaning of the powder particle surface; (2) formation of 'necks' between particles; (3) growth of the 'necks' already formed; and (4) consolidation of material as a result of its plastic deformation. Due to the combined

(isulima@up.krakow.pl) effect of all these phenomena, activation of the sintering process is accelerated and grain growth restricted. It also allows the process temperature to be reduced by as much as $200-500^{\circ} \mathrm{C}^{12,13}$

Analysis of literature indicates that numerous research works were devoted to the problem of sintering the austenitic stainless steel by the pressure-free technique. Yet, in the case of austenitic stainless steel, conventional methods of sintering give sinters that are characterized by unfavourable mechanical properties, additionally enhanced by poor corrosion resistance in various corrosive environments. This is the consequence of the porous structure of the sintered steel, which can cause cracking and pitting. Properties of sintered austenitic steels depend on many factors such as the physicochemical and technical properties of powder, the method and pressure of compaction, and the sintering temperature, time and atmosphere C. ${ }^{10,14-16}$ In the case of austenitic steels, an important factor shaping the properties of the sintered products is the atmosphere of sintering. ${ }^{17}$ Proper sintering atmosphere helps in the reduction of oxidation of the steel powder particles and the content of carbon, nitrogen and oxygen in the sinter. Molinari et al have shown that the use of a hydrogen atmosphere in the sintering process allows obtaining the best functional properties of austenitic stainless steel. ${ }^{18}$ Another important factor is the use of proper sintering additive. ${ }^{19,20}$ Boron has been considered as the element playing a very important role in the sintering process of austenitic steels. It segregates at grain boundaries, thereby reducing energy. Additionally, boron forms in these steels complex borides of iron, nickel and chromium. As proved by the tests and studies, appropriate amount of boron additive to the mixture of iron powders effectively activates 
the sintering process. At the sintering temperature higher than the temperature of eutectic transformation, a liquid phase appears and an obvious consequence of this fact is the sinter densification and changes in its structure. This, in turn, improves the strength properties of the sintered austenitic steel. ${ }^{21-25}$ Therefore, in this study, an attempt has been made to explain the effect of the addition of boron on the properties and microstructure of composites based on the austenitic steel and produced by SPS.

\section{Experimental}

The starting materials used in this research included the AISI 316L austenitic stainless-steel matrix (particle size about $25 \mu \mathrm{m}$, Hoganas) in the form of powder forming a metallic matrix of the composite and further $\mathrm{TiB}_{2}$ (particle size of $2.5-3.5 \mu \mathrm{m}$, H.C. Starck) and boron (particle size of 5-7 $\mu \mathrm{m}$, Goodfellows). The initial phase composition of the obtained mixtures was: (a) AISI 316L steel +8 vol\% $\mathrm{TiB}_{2}$ and (b) AISI $316 \mathrm{~L}$ steel $+8 \mathrm{vol} \% \mathrm{TiB}_{2}+1 \mathrm{vol} \% \mathrm{~B}$. The constituents were mixed in a TURBULA mixer for $8 \mathrm{~h}$.

The powders were densified by the SPS-HPD 5 type technique (FCT System, Germany). They were poured into a graphite die of $20 \mathrm{~mm}$ inner diameter, and the die was placed between the graphite electrodes in an SPS chamber. The process of compaction was conducted in vacuum under a maximum pressure of $35 \mathrm{MPa}$. The maximum pressure was obtained after $10 \mathrm{~min}$ of the test duration. Both the vacuum and the pressing time of $10 \mathrm{~min}$ were applied in order to 'vent' the mixture. After this step, argon acting as a protective gas was introduced into the SPS furnace chamber, and the sintering process continued. The powders were sintered at 1000 and $1100^{\circ} \mathrm{C}$ for 5 and $30 \mathrm{~min}$. A heating rate of $200^{\circ} \mathrm{C} \mathrm{min}^{-1}$ was used for all materials. Finally, the sintered cylindrical samples of $20 \mathrm{~mm}$ diameter and $8 \mathrm{~mm}$ height were produced.

The relative density was determined by the Archimedes method using distilled water as a wetting liquid. The microstructure of the sintered materials was examined by SEM Hitachi SU-70 with wavelength dispersive spectroscopy (WDS) and by SEM INSPECT F50 (FEI) equipped with electron backscatter diffraction (EBSD).
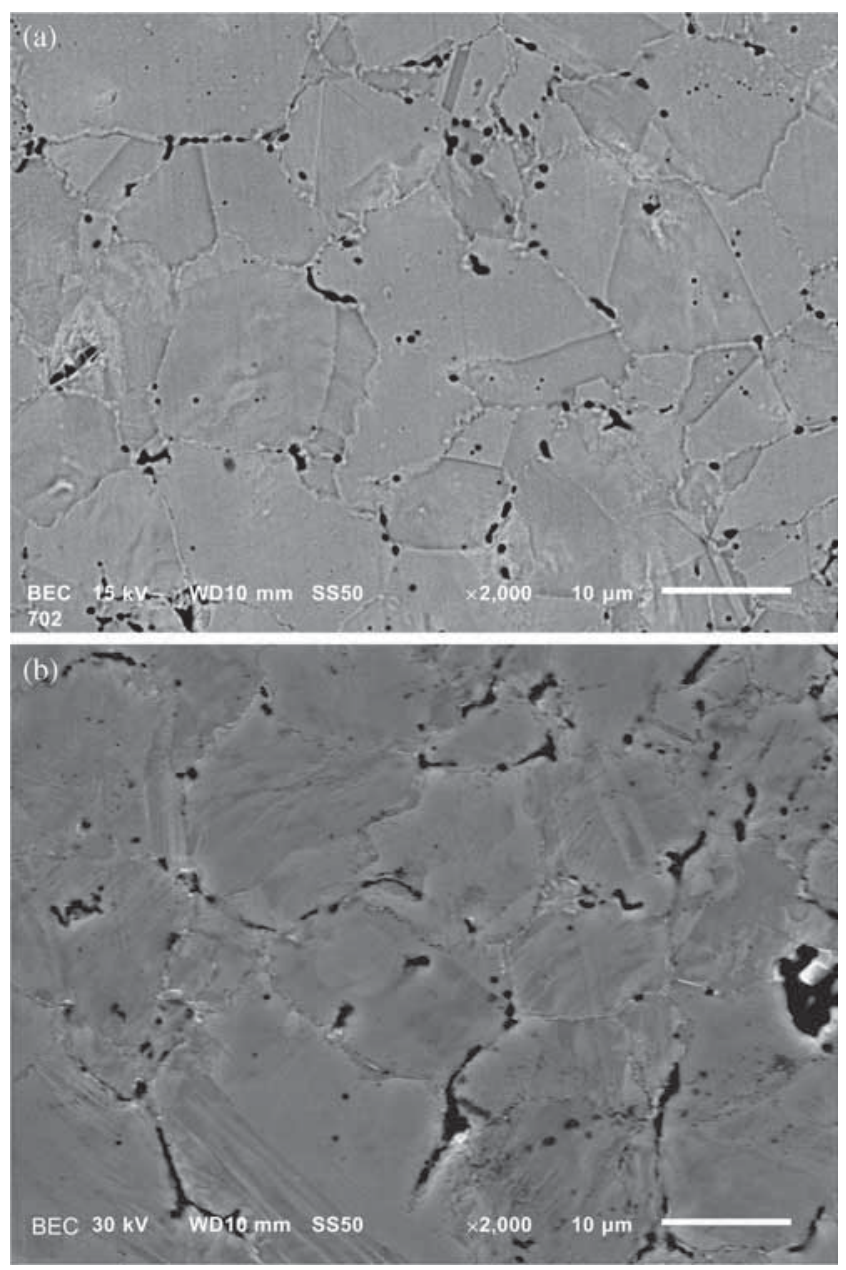

Figure 1. SEM micrograph of the AISI 316L steel sintered at: (a) $1100^{\circ} \mathrm{C}-5 \mathrm{~min}$ and (b) $1100^{\circ} \mathrm{C}-30 \mathrm{~min}$.

Table 1. Physical properties of AISI 316L steel and composites sintered by the SPS method.

\begin{tabular}{|c|c|c|c|c|c|c|c|}
\hline \multirow{2}{*}{$\begin{array}{l}\text { Sintered } \\
\text { materials }\end{array}$} & \multicolumn{2}{|c|}{ Sintering conditions } & \multirow{2}{*}{$\begin{array}{c}\text { Apparent density } \\
\rho_{0}\left(\mathrm{~g} \mathrm{~cm}^{-3}\right)\end{array}$} & \multirow{2}{*}{$\begin{array}{c}\rho_{0} / \rho_{\text {teor }} \\
(\%)\end{array}$} & \multirow{2}{*}{$\begin{array}{c}\text { Porosity } \\
\text { (\%) }\end{array}$} & \multirow{2}{*}{$\begin{array}{c}\text { Young's } \\
\text { modulus } E(\mathrm{GPa})\end{array}$} & \multirow{2}{*}{$\begin{array}{c}E / E_{\text {teor }} \\
(\%)\end{array}$} \\
\hline & $T\left({ }^{\circ} \mathrm{C}\right)$ & Time (min) & & & & & \\
\hline Steel AISI 316L & $\begin{array}{l}1000 \\
1100 \\
1000 \\
1100\end{array}$ & 30 & $\begin{array}{l}6.73 \pm 0.03 \\
7.75 \pm 0.01 \\
6.87 \pm 0.02 \\
7.82 \pm 0.02\end{array}$ & $\begin{array}{l}83 \pm 0.3 \\
97 \pm 0.3 \\
86 \pm 0.3 \\
98 \pm 0.3\end{array}$ & $\begin{array}{c}15.32 \\
0.92 \\
11.65 \\
0.89\end{array}$ & $\begin{array}{l}165 \pm 3 \\
196 \pm 5 \\
176 \pm 3 \\
208 \pm 4\end{array}$ & $\begin{array}{l}79 \pm 1 \\
94 \pm 2 \\
84 \pm 1 \\
99 \pm 1\end{array}$ \\
\hline Steel-8\% $\mathrm{TiB}_{2}$ & $\begin{array}{l}1000 \\
1100 \\
1000 \\
1100\end{array}$ & 30 & $\begin{array}{l}6.29 \pm 0.02 \\
7.53 \pm 0.02 \\
7.02 \pm 0.03 \\
7.52 \pm 0.01\end{array}$ & $\begin{array}{l}82 \pm 0.3 \\
98 \pm 0.3 \\
90 \pm 0.3 \\
98 \pm 0.3\end{array}$ & $\begin{array}{l}17.27 \\
0.034 \\
10.56 \\
0.006\end{array}$ & $\begin{array}{l}166 \pm 3 \\
215 \pm 4 \\
171 \pm 4 \\
212 \pm 4\end{array}$ & $\begin{array}{l}67 \pm 1 \\
91 \pm 2 \\
72 \pm 2 \\
90 \pm 2\end{array}$ \\
\hline Steel-8\% $\mathrm{TiB}_{2}-1 \% \mathrm{~B}$ & $\begin{array}{l}1000 \\
1100 \\
1000 \\
1100\end{array}$ & 30 & $\begin{array}{l}6.83 \pm 0.03 \\
7.83 \pm 0.01 \\
7.18 \pm 0.03 \\
7.87 \pm 0.02\end{array}$ & $\begin{array}{l}86 \pm 0.3 \\
98 \pm 0.3 \\
90 \pm 0.3 \\
99 \pm 0.3\end{array}$ & $\begin{array}{l}12.95 \\
0.076 \\
11.06 \\
0.002\end{array}$ & $\begin{array}{l}176 \pm 3 \\
222 \pm 4 \\
198 \pm 4 \\
229 \pm 4\end{array}$ & $\begin{array}{l}75 \pm 2 \\
96 \pm 2 \\
84 \pm 1 \\
97 \pm 2\end{array}$ \\
\hline
\end{tabular}



composites were additionally evaluated with an ultra-highresolution scanning electron microscope (TEM Tecnai G2 20XT; $200 \mathrm{kV}$ ) equipped with an EDX and STEM detector.

Young's modulus value was derived from ultrasonic sound velocity measurements (detector Panametric Epoch III). The accuracy of the calculated Young's modulus was estimated at $2 \%$. The microhardness was measured in an indentation test using a Vickers diamond indenter (NEXUS 4000). The applied load was equal to $2.942 \mathrm{~N}$. The average microhardness was evaluated from at least 15 indentations made on each sample. The compression test was carried out on an INSTRON TT-DM machine at a strain rate of about of $10^{-3} \mathrm{~s}$. These tests were performed on the $3 \mathrm{~mm}$ diameter specimens of $4.5 \mathrm{~mm}$ height. The mechanical tests were carried out at room temperature and at 600 and $800^{\circ} \mathrm{C}$. The tests at elevated temperatures were performed in a protective atmosphere of argon.

The wear behaviour was measured in a ball-on-disc test. Wear tests were carried out using the following test conditions: ball made of $\mathrm{Al}_{2} \mathrm{O}_{3}$ (3.175 $\mathrm{mm}$ diameter); friction
The microstructure and the composition of the obtained

track diameter of $4 \mathrm{~mm}$; sliding distance of $200 \mathrm{~m}$; speed of $0.1 \mathrm{~m} \mathrm{~s}^{-1}$; applied load of $4 \mathrm{~N}$, test duration of $2000 \mathrm{~s}$; and room temperature. Additionally, for selected composites, the tribological tests were carried out at a temperature of 600 and $800^{\circ} \mathrm{C}$.

The values of friction coefficient were calculated from the following equation:

$$
\mu=\frac{F_{\mathrm{f}}}{F_{\mathrm{n}} L},
$$

where $F_{\mathrm{f}}$ is the measured friction force $(\mathrm{N}) ; F_{\mathrm{n}}$ the applied normal force $(\mathrm{N})$; and $L$ the sliding distance $(\mathrm{m})$.

The specific wear rate based on the wear volume was calculated by means of the following equation:

$$
W_{V(\text { disc })}=\frac{V_{\text {disc }}}{F_{\mathrm{n}} L},
$$

where $V_{\text {disc }}$ is the wear volume of disc specimen $\left(\mathrm{mm}^{3}\right) ; F_{\mathrm{n}}$ the applied normal load $(\mathrm{N})$; and $L$ the sliding distance $(\mathrm{m})$.
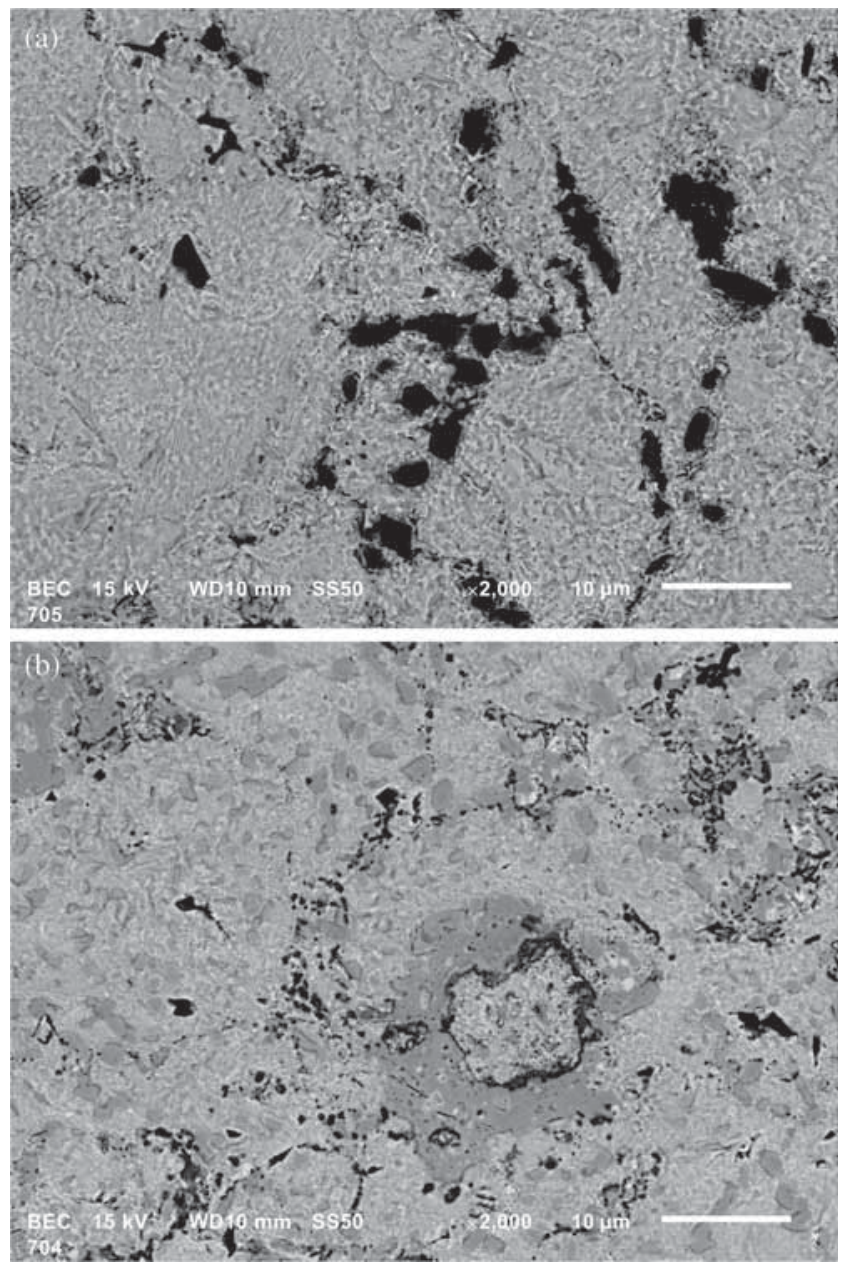

Figure 3. SEM micrograph of the steel-8\% $\mathrm{TiB}_{2}-1 \% \mathrm{~B}$ composite sintered at: (a) $1100^{\circ} \mathrm{C}-5 \mathrm{~min}$ and (b) $1100^{\circ} \mathrm{C}-30 \mathrm{~min}$.
Figure 2. SEM micrograph of the steel-8\% $\mathrm{TiB}_{2}$ composite sin-

tered at: (a) $1100^{\circ} \mathrm{C}-5 \mathrm{~min}$ and (b) $1100^{\circ} \mathrm{C}-30 \mathrm{~min}$.
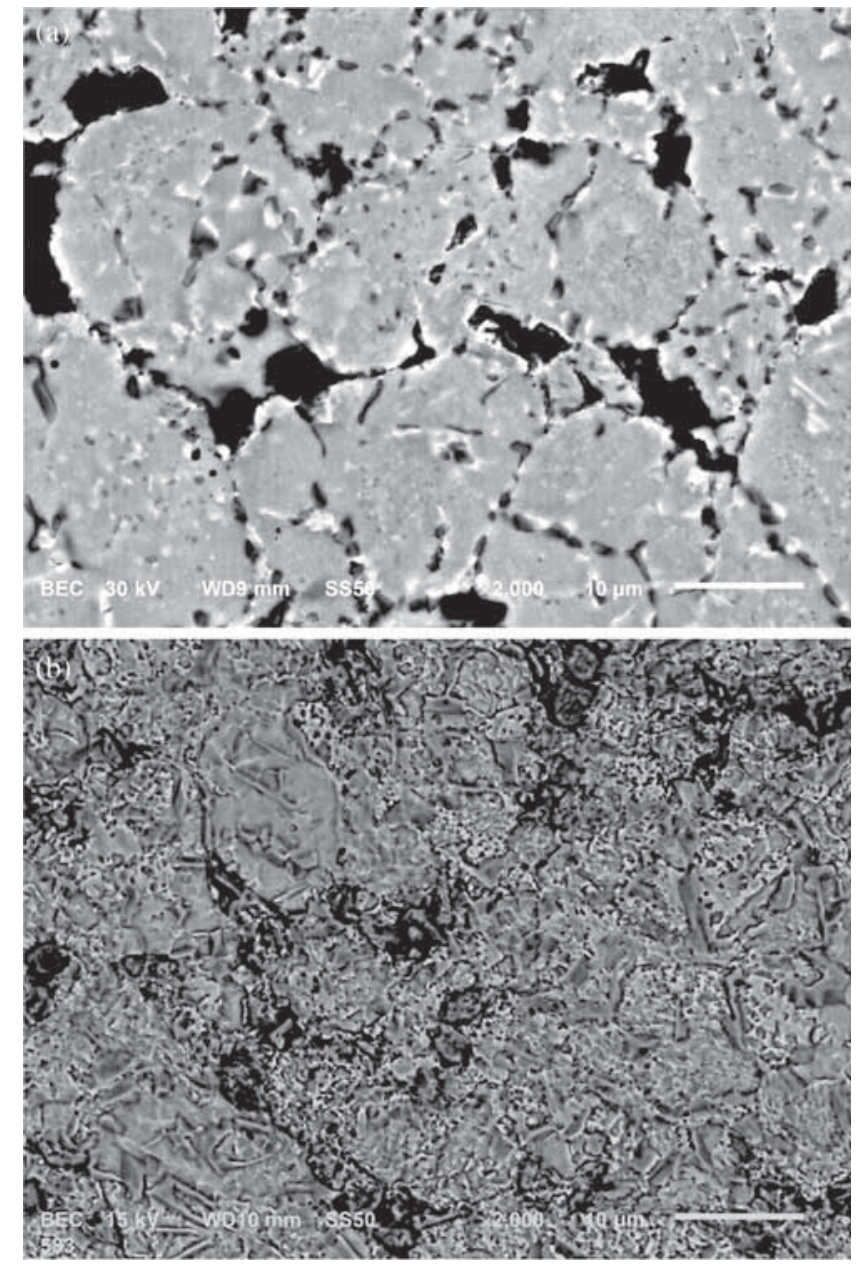


\section{Results and discussion}

Table 1 shows the effect of boron addition on the physical properties of sintered materials. The temperature of $1000^{\circ} \mathrm{C}$ has proved to be highly disadvantageous for the consolidation of composites based on austenitic steel. Sinters obtained under such conditions were characterized by a low density of $82-90 \%$ and high porosity in the range of $11-17 \%$. A significant improvement in the density of the sintered material was observed with an increase of the sintering temperature $\left(1100^{\circ} \mathrm{C}\right)$. A very high density in the range of $97-$ $99 \%$ of the theoretical value was obtained in these materials, with the porosity kept at a minimum level of $0.002-0.092 \%$. SPS simultaneously applying pulsed electrical current and pressure directly on the composite has led to the densification at a relatively low temperature. It should be noted that sintering of austenitic stainless steel by conventional methods is carried out at temperatures above $1200^{\circ} \mathrm{C}$. The authors $^{21,22,26}$ have demonstrated that boron is an effective activator of the sintering process of stainless-steel powders. It has been found that boron in small amounts activates the sintering process due to the appearance of a liquid wetting the surfaces of the powder particles, and thus contributing to an increase in the sintered compact density. For example, the addition of $0.5 \mathrm{wt} \%$ boron dramatically increased the sintered density of $316 \mathrm{~L}$ stainless steel from 6.96 to $7.9 \mathrm{~g} \mathrm{~cm}^{-3}$, while reducing the sintering temperature from 1350 to $1245^{\circ} \mathrm{C}$ and the isothermal hold time from 120
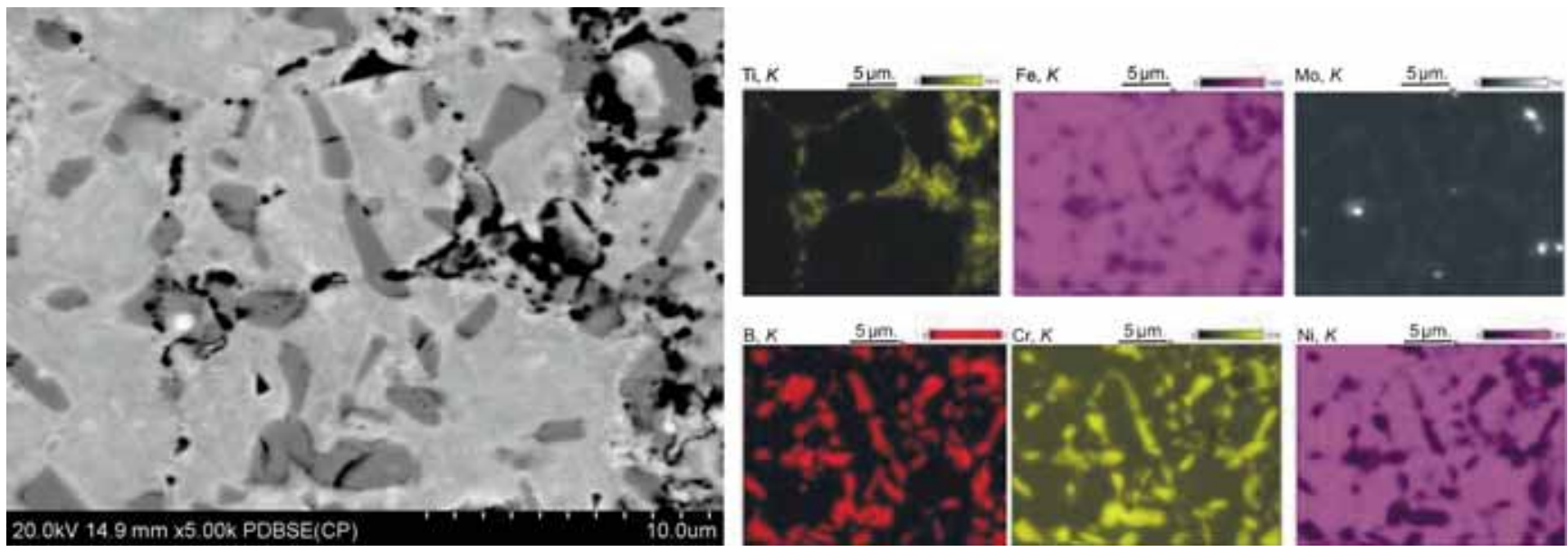

Figure 4. Microstructure (SEM) of the steel-8\% $\mathrm{TiB}_{2}-1 \% \mathrm{~B}$ composite and the element distribution maps by WDS analysis for titanium, boron, chromium, iron, nickel and molybdenum $\left(1100^{\circ} \mathrm{C}-5 \mathrm{~min}\right)$.
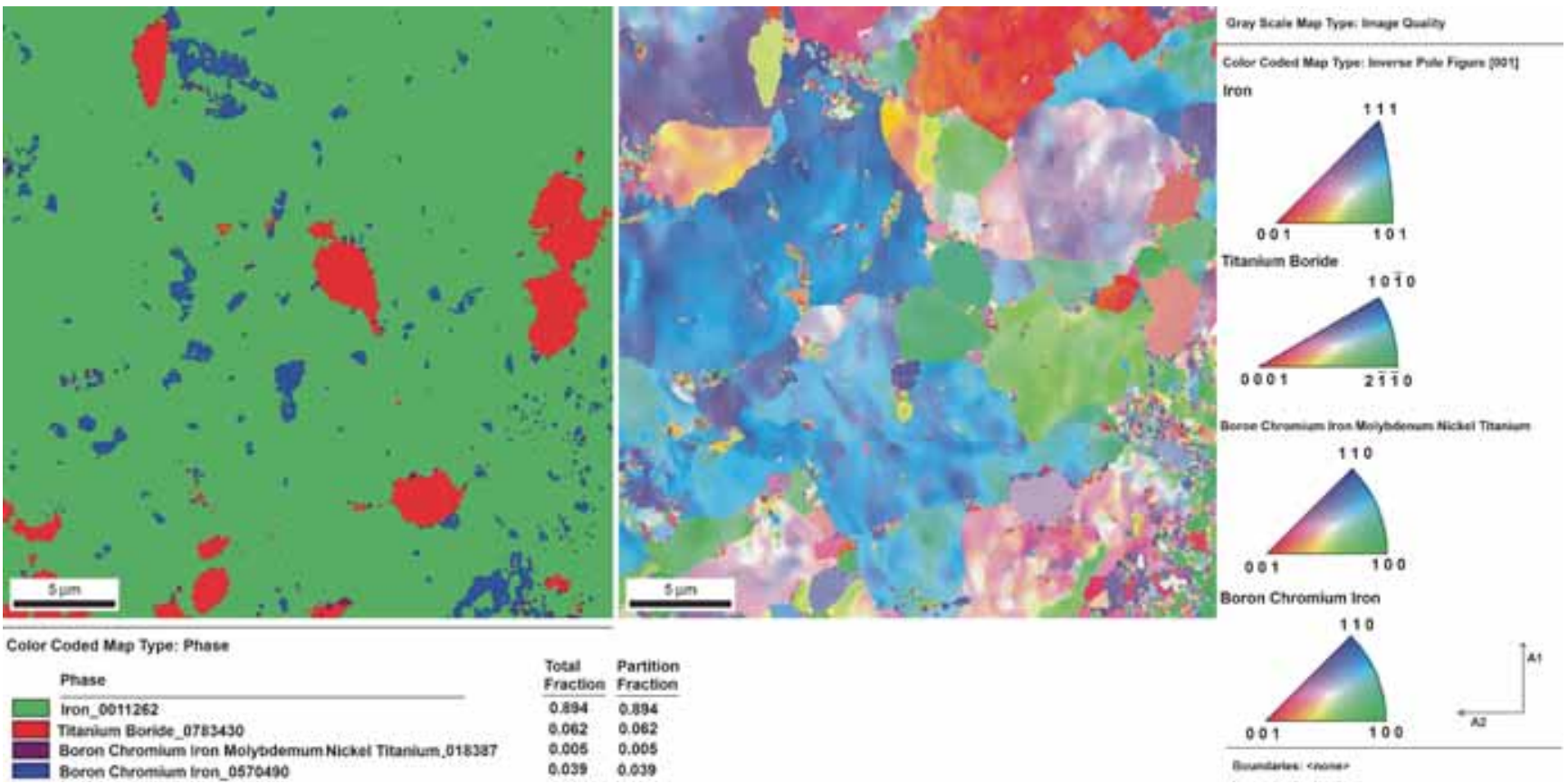

Figure 5. EBSD images for steel- $8 \% \mathrm{TiB}_{2}-1 \% \mathrm{~B}$ composite. 
to 45 min. ${ }^{27}$ Pellizzari et al ${ }^{28}$ were investigating the consolidation by SPS of high speed steel (AISI M2) and hot work tool steel (AISI H13). It has been proved that the density increases with the increase in temperature up to 1050 and $1100^{\circ} \mathrm{C}$, a minor influence of time being observed for times longer than 5 min. Nearly full density (>99.5\%) accompanied by good microstructure and hardness could be obtained after sintering at $1100^{\circ} \mathrm{C}$ for $5 \mathrm{~min}$.

Figures 1-3 compare the microstructure of the sintered stainless austenitic steel and of the steel-8\% $\mathrm{TiB}_{2}$ and steel$8 \% \mathrm{TiB}_{2}-1 \% \mathrm{~B}$ composites, examined as a function of the sintering time (for the temperature of $1100^{\circ} \mathrm{C}$ ). The microstructure of the tested composites (figures 2 and 3) is characterized by a uniform distribution of the particles of the reinforcing $\mathrm{TiB}_{2}$ phase (black areas) along the grain boundaries in the matrix. A uniform distribution of the $\mathrm{TiB}_{2}$ particles is required to obtain proper mechanical and tribological properties. Microstructural analysis (SEM and WDS) in the steel matrix has revealed the presence of numerous fine precipitates containing chromium (e.g., grey precipitates in figures 3 and 4). Such precipitates were not observed in the sintered austenitic steel. Further observations of the microstructure showed that different SPS process conditions affected the microstructure of the tested materials. With the increasing time and temperature of sintering, an increase in the number of new chromium phases and in their size was observed throughout the entire composite volume. The use of EBSD in the study allowed identification of phases in the microstructure of sintered composites. Figure 5 shows examples of the results of the EBSD analysis in the form of maps illustrating the phase analysis of microstructure in the steel-8\% $\mathrm{TiB}_{2}-1 \% \mathrm{~B}$ composite. The presence of the following phases was revealed in the composite microstructure: $\mathrm{Fe}, \mathrm{TiB}_{2}$ and two complex borides $\left(\mathrm{BCr}_{0.2} \mathrm{Fe}_{1.8}\right.$ and (Cr, Fe, Mo, Ni, Ti $)_{3} \mathrm{~B}_{2}$ ). Boride phases of $\mathrm{BCr}_{0.2} \mathrm{Fe}_{1.8}$ and $(\mathrm{Cr}, \mathrm{Fe}, \mathrm{Mo}, \mathrm{Ni}, \mathrm{Ti})_{3} \mathrm{~B}_{2}$ had the tetragonal structure with lattice parameters of $a=5.098 \AA, c=4.226 \AA$ and $a=5.783 \AA$, $c=3.134 \AA$, respectively. ${ }^{29}$ It should be noted that studies described in references ${ }^{21,30}$ have demonstrated the formation of complex borides ( $\mathrm{Cr}, \mathrm{Mo}, \mathrm{Fe}$ ) in the process of pressurefree sintering of austenitic stainless steel. In those studies, a small amount of boron was used as a sintering activator. The analysis of a binary $\mathrm{Fe}-\mathrm{B}$ phase diagram leads to the conclusion that boron is an ideal sintering additive. The eutectic reaction $\left(\mathrm{Fe}_{2} \mathrm{~B}+\mathrm{Fe} \rightarrow\right.$ liquid) occurs at $1174^{\circ} \mathrm{C} .^{31,32}$ The liquid phase has a very low solubility in iron and provides a continuous network between the solid grains. ${ }^{33}$ It was observed that during sintering of the austenitic stainless steel modified with boron a liquid phase was formed. The formation of this phase is thought to be the result of a eutectic reaction taking place between the alloy matrix of the base alloy and a complex borides ( $\mathrm{Cr}, \mathrm{Mo}, \mathrm{Fe})$. The presence of borides improves the mechanical properties and corrosion resistance of materials. ${ }^{21,34-36}$

The applied sintering conditions and complex mechanisms occurring during the SPS process promote accelerated diffusion and formation of new phases (complex borides) in the steel matrix composites (figures 4 and 5). Boron in the steel matrix acts as an additional activator of the complex borides formation under the SPS process conditions. This has been confirmed by microstructural studies, which showed that the observed content of complex borides was higher in the steel-8\% $\mathrm{TiB}_{2}-1 \% \mathrm{~B}$ composite than in the steel-8\% $\mathrm{TiB}_{2}$ system. Figure 6 shows the results of microstructural examinations made by TEM on the steel-8\% $\mathrm{TiB}_{2}-1 \% \mathrm{~B}$ composite. Numerous fine precipitates of the size of less than $500 \mathrm{~nm}$ arranged in a steel matrix were observed. A typical microstructure of the phase boundary formed between
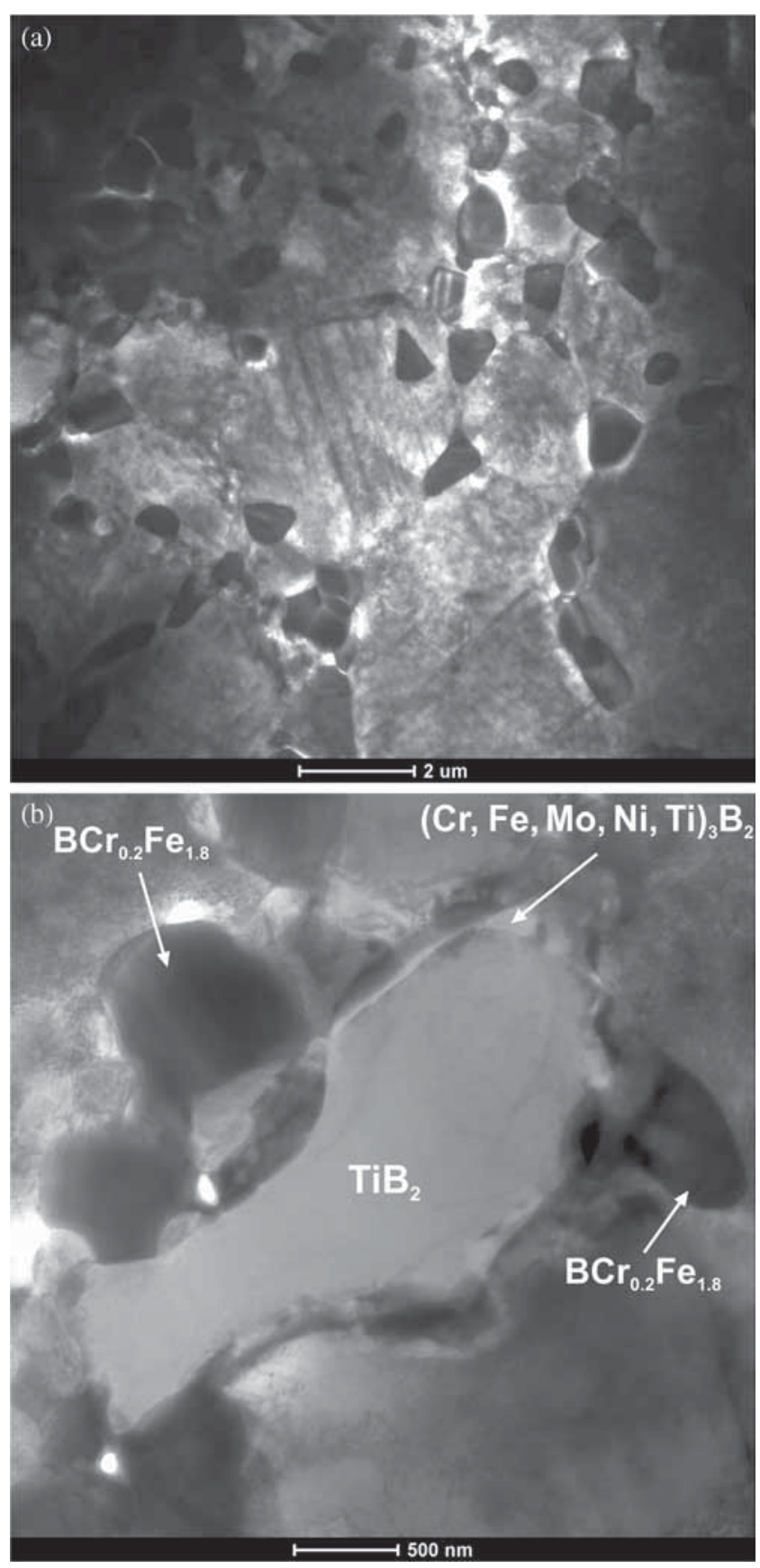

Figure 6. (a and b) TEM observations of steel-8\% $\mathrm{TiB}_{2}-1 \% \mathrm{~B}$ composite. 
the matrix and the reinforcing particles of $\mathrm{TiB}_{2}$ is shown in figure 7. Numerous fine precipitates forming an envelope around the $\mathrm{TiB}_{2}$ particles with the tendency to nucleate and grow on the $\mathrm{TiB}_{2}$ phase boundary were noticed (figures 6 and 7). Chemical analysis of these phases has confirmed the presence in the microstructure of complex borides with the composition corresponding to the composition of phases identified by EBSD $\left(\mathrm{BCr}_{0.2} \mathrm{Fe}_{1.8}\right.$ and $(\mathrm{Cr}, \mathrm{Fe}, \mathrm{Mo}$, $\mathrm{Ni}, \mathrm{Ti})_{3} \mathrm{~B}_{2}$ ). The dominant boride phase is the $\mathrm{BCr}_{0.2} \mathrm{Fe}_{1.8}$ phase of the size from 1 to $2 \mu \mathrm{m}$ (dark precipitates in figure 6). In contrast, the light-coloured fine precipitates of the size from 100 to $500 \mathrm{~nm}$ (figure 6b) correspond to the $(\mathrm{Cr}, \mathrm{Fe}, \mathrm{Mo}, \mathrm{Ni}, \mathrm{Ti})_{3} \mathrm{~B}_{2}$ phase.

The addition of boron to the matrix has improved Young's modulus, especially in the case of composites sintered at a temperature of $1100^{\circ} \mathrm{C}$ (table 1). For the temperature of $1100^{\circ} \mathrm{C}$, Young's modulus values for the steel $-8 \% \mathrm{TiB}_{2}$ composite were $215 \pm 4$ and $212 \pm 4 \mathrm{GPa}$ for the time of 5 and $30 \mathrm{~min}$, respectively, while for the steel- $8 \% \mathrm{TiB}_{2}-1 \%$ B composite, they amounted to $222 \pm 4$ and $229 \pm 4 \mathrm{GPa}$, respectively. Low values of Young's modulus were obtained for the temperature of $1000^{\circ} \mathrm{C}$, which was associated with a high level of porosity observed in sinters produced under these conditions. Tanaka and Saito ${ }^{37}$ reported an increase in Young's modulus of AISI 430 steel with the increasing addition of $\mathrm{TiB}_{2}$ reinforcement. The increase in Young's modulus of the steel-based composites with $\mathrm{TiB}_{2}$ reinforcement has been reported in other studies, too. ${ }^{38,39}$

Microhardness test results are shown in figure 8. Studies of the effect of boron addition showed marked improvement in the microhardness of boron-modified composites with 8 vol\% $\mathrm{TiB}_{2}$ as compared to composites unmodified. The microhardness of steel- $8 \% \mathrm{TiB}_{2}-1 \% \mathrm{~B}$ composites was 410-465 ( $\pm 16-18)$ HV0.3, depending on the applied conditions of SPS. A significant improvement was observed in the microhardness of steel- $8 \% \mathrm{TiB}_{2}-1 \% \mathrm{~B}$ composites sintered at a temperature of $1000^{\circ} \mathrm{C}$. For these materials, an almost twofold increase in the microhardness values was reported, i.e., by $200 \pm 8$ (figure 8a) HV0.3 and $160 \pm 6$ (figure 8b) $\mathrm{HV} 0.3$ for the sintering conditions of $1000^{\circ} \mathrm{C}-$ $5 \mathrm{~min}$ and $1000^{\circ} \mathrm{C}-30 \mathrm{~min}$, respectively. The steel $-8 \% \mathrm{TiB}_{2}-$ $1 \% \mathrm{~B}$ composite sintered at a higher temperature of $1100^{\circ} \mathrm{C}$ showed an increase of microhardness in the range of 20 $40 \%$, compared with the steel- $8 \% \mathrm{TiB}_{2}$ composite. This was
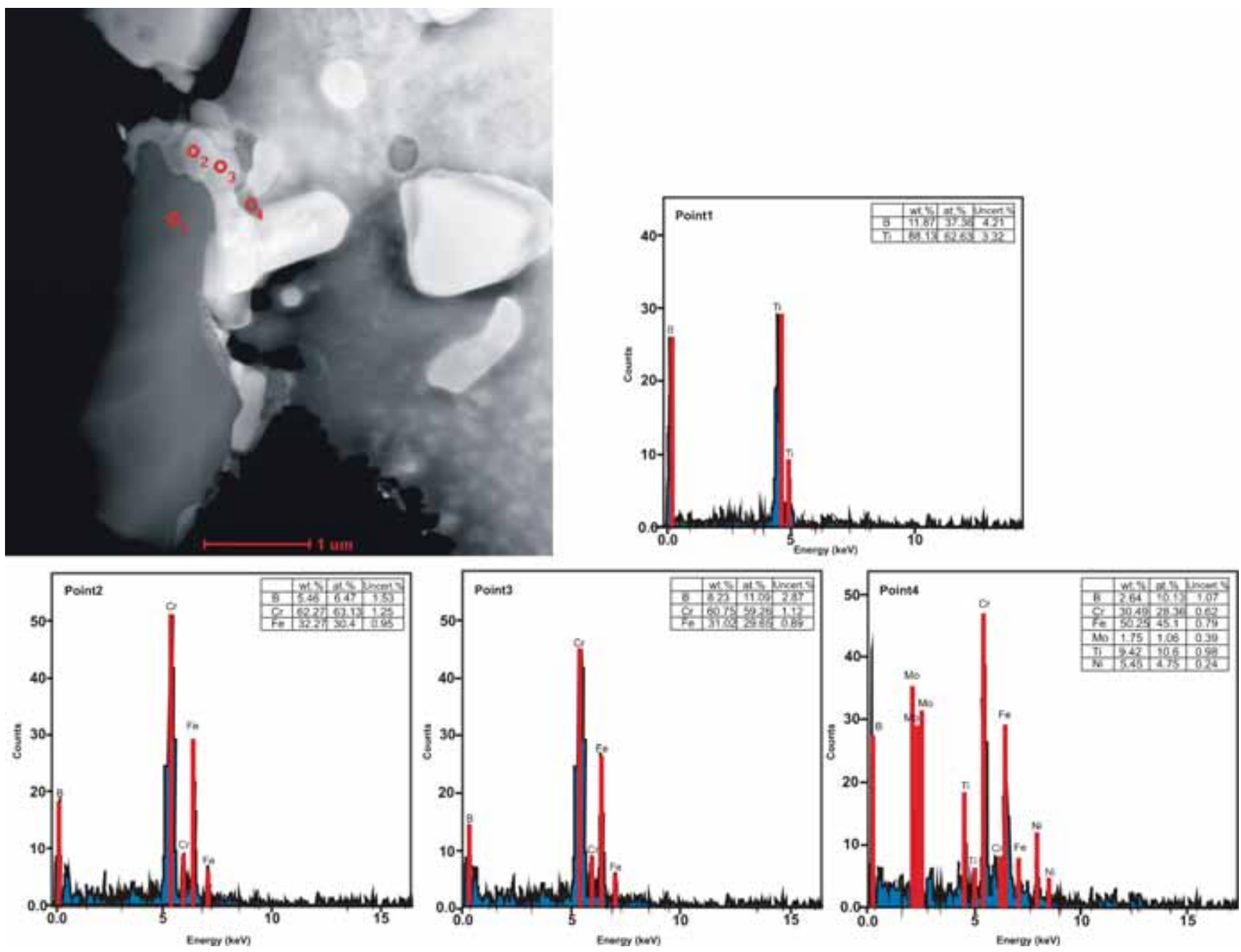

Figure 7. TEM observations of steel- $8 \% \mathrm{TiB}_{2}-1 \% \mathrm{~B}$ composite. 

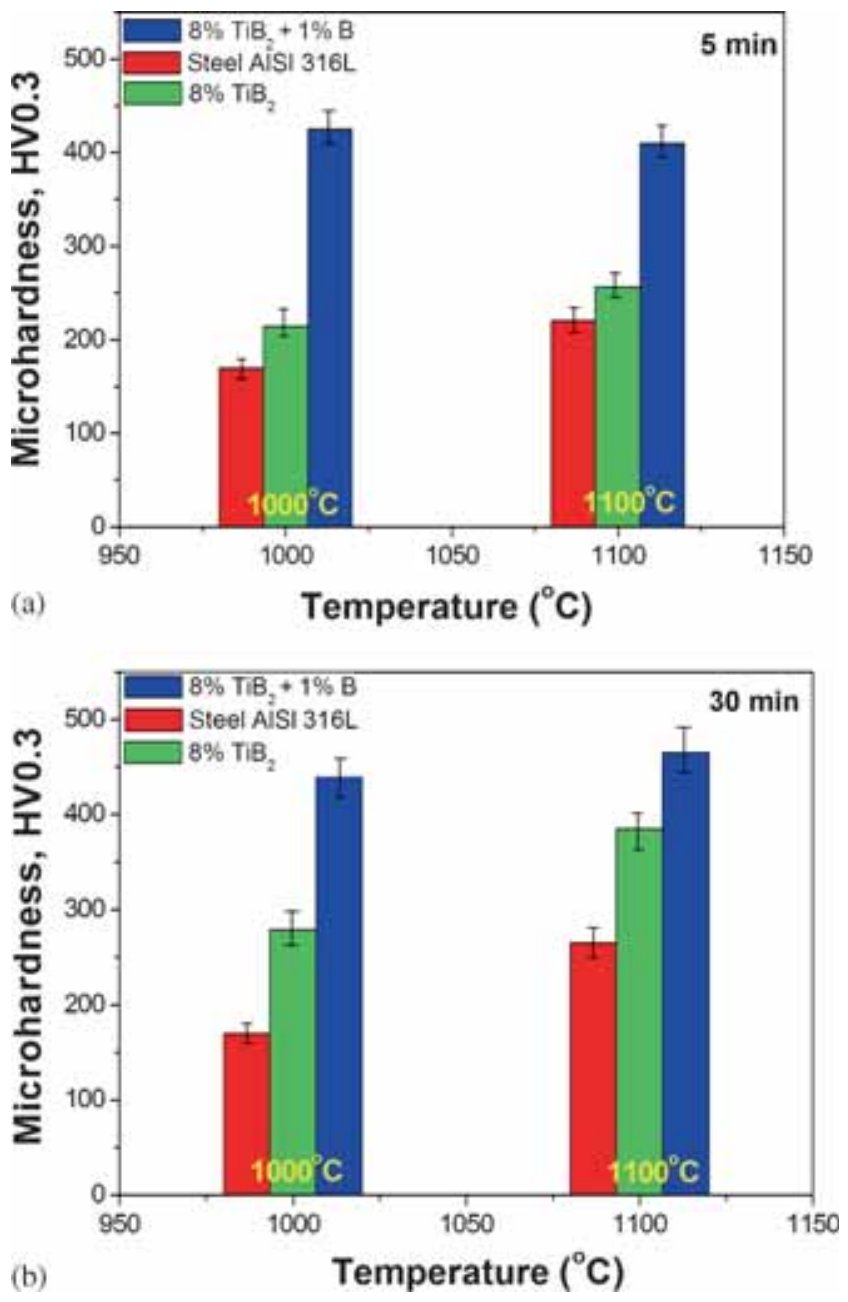

Figure 8. Effect of boron addition on the microhardness of composites sintered by SPS for: (a) $5 \mathrm{~min}$ and (b) $30 \mathrm{~min}$.

the result of microstructural changes. The presence of fine complex borides probably improved the microhardness of sintered steel $-8 \% \mathrm{TiB}_{2}-1 \% \mathrm{~B}$ composites.

Figure 9 and table 2 compare the results of compressive strength testing carried out on steel and respective composites, including tests at elevated temperatures. Additionally, charts show selected results of compression tests carried out on the steel without reinforcement, which was sintered at $1100^{\circ} \mathrm{C}-30 \mathrm{~min}$ (figure 9a). Steel sintered at $1100^{\circ} \mathrm{C}-30 \mathrm{~min}$ was characterized by the highest compressive strength of about $560 \mathrm{MPa}$. Steel sintered at $1000^{\circ} \mathrm{C}-5 \mathrm{~min}$ and $1000^{\circ} \mathrm{C}-$ 30 min was characterized by lower compressive strength of 470-500 MPa. Generally, the introduction of $\mathrm{TiB}_{2}$ to the steel matrix improved the compressive strength of composites sintered at a temperature of $1100^{\circ} \mathrm{C}$. No deterioration of plastic properties was observed in the sintered materials. The introduction of a ceramic phase is one of the possibilities to strengthen the composites. The phenomenon of composite strengthening can also be controlled by the grain growth inhibition effect, or by the matrix grain refinement. ${ }^{40}$ Modern methods of sintering, the SPS method included,
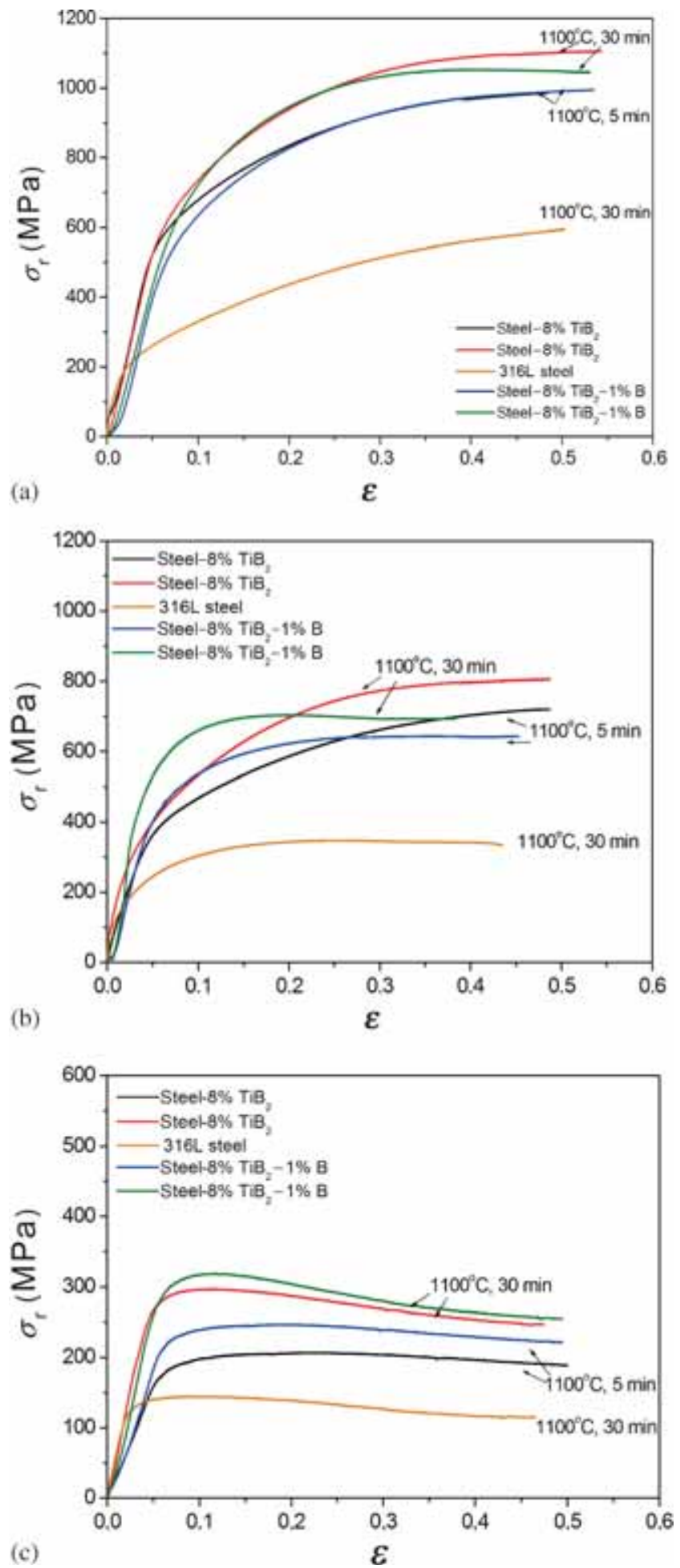

Figure 9. Results of the compression test carried out at: (a) room temperature, (b) $600^{\circ} \mathrm{C}$ and (c) $800^{\circ} \mathrm{C}$ for composites sintered at $1100^{\circ} \mathrm{C}$

enable, among others, reducing the processing time compared to conventional sintering methods, ${ }^{41,42}$ and this, in turn, contributes to the inhibited grain growth.

The results showed that boron addition introduced to the composite matrix did not significantly alter the mechanical 
Table 2. Compression strength of AISI 316L steel and composites sintered by the SPS method.

\begin{tabular}{|c|c|c|c|c|c|}
\hline \multirow{2}{*}{$\begin{array}{l}\text { Sintered } \\
\text { materials }\end{array}$} & \multicolumn{2}{|c|}{$\begin{array}{l}\text { Sintering } \\
\text { conditions }\end{array}$} & \multirow{2}{*}{$\begin{array}{l}\text { Compression } \\
\text { strength }(\mathrm{MPa}) \\
\text { obtained at } \\
\text { room } \\
\text { temperature }\end{array}$} & \multirow{2}{*}{$\begin{array}{l}\text { Compression } \\
\text { strength }(\mathrm{MPa}) \\
\text { obtained at } \\
600^{\circ} \mathrm{C}\end{array}$} & \multirow{2}{*}{$\begin{array}{l}\text { Compression } \\
\text { strength }(\mathrm{MPa}) \\
\text { obtained at } \\
600^{\circ} \mathrm{C}\end{array}$} \\
\hline & $T\left({ }^{\circ} \mathrm{C}\right)$ & Time (min) & & & \\
\hline \multirow[t]{4}{*}{ Steel AISI 316L } & 1000 & 5 & $470 \pm 14$ & $270 \pm 9$ & $125 \pm 4$ \\
\hline & 1100 & & $520 \pm 15$ & $311 \pm 9$ & $124 \pm 4$ \\
\hline & 1000 & 30 & $500 \pm 15$ & $335 \pm 10$ & $132 \pm 4$ \\
\hline & 1100 & & $560 \pm 17$ & $340 \pm 10$ & $135 \pm 4$ \\
\hline \multirow[t]{4}{*}{ Steel-8\% $\mathrm{TiB}_{2}$} & 1000 & 5 & $520 \pm 15$ & $435 \pm 13$ & $176 \pm 5$ \\
\hline & 1100 & & $988 \pm 30$ & $572 \pm 17$ & $184 \pm 5$ \\
\hline & 1000 & 30 & $620 \pm 18$ & $720 \pm 21$ & $207 \pm 6$ \\
\hline & 1100 & & $1114 \pm 34$ & $820 \pm 24$ & $295 \pm 9$ \\
\hline \multirow[t]{4}{*}{ Steel-8\% $\mathrm{TiB}_{2}-1 \% \mathrm{~B}$} & 1000 & 5 & $582 \pm 17$ & $405 \pm 12$ & $139 \pm 4$ \\
\hline & 1100 & & $955 \pm 30$ & $450 \pm 13$ & $179 \pm 5$ \\
\hline & 1000 & 30 & $640 \pm 18$ & $644 \pm 19$ & $246 \pm 7$ \\
\hline & 1100 & & $1055 \pm 32$ & $710 \pm 21$ & $319 \pm 9$ \\
\hline
\end{tabular}

properties of the composite within the entire temperature range of the conducted compression tests (table 2). Generally, the steel-8\% $\mathrm{TiB}_{2}$ and steel-8\% $\mathrm{TiB}_{2}-1 \%$ B composites exhibited the same shear strength. In contrast, it was observed that the compressive strength was strongly influenced by the sintering conditions, the sintering temperature-in particular. The compressive strength of all the composites fabricated by sintering at $1000^{\circ} \mathrm{C}$ was at a level of 520-640 MPa. Higher sintering temperature $\left(1100^{\circ} \mathrm{C}\right)$ resulted in a nearly twofold increase of its value.

The increase of temperature during compression tests has obviously deteriorated the composite mechanical properties. Composites compressed at $600^{\circ} \mathrm{C}$ were characterized by the highest strength of 820 and $710 \mathrm{MPa}$ obtained for the steel$8 \% \mathrm{TiB}_{2}$ composite and steel-8\% $\mathrm{TiB}_{2}-1 \% \mathrm{~B}$ composite, respectively (sintering at $1100^{\circ} \mathrm{C}$ for $30 \mathrm{~min}$; figure $9 \mathrm{~b}$ ). For the steel without reinforcement, the compressive strength was at a level of about 270-340 MPa, depending on the sintering conditions. Raising the temperature during the compression test to $800^{\circ} \mathrm{C}$ has resulted in a drastic drop of the composite strength (figure 9c), making it three times lower compared to the strength obtained in tests carried out at room temperature.

Tribological studies by the ball-on-disc method showed an improvement in the tribological properties of composites due to the addition of $\mathrm{TiB}_{2}$ ceramics to the steel matrix (figures 10 and 11). This is consistent with the investigations done by Tjong and $\mathrm{Lau}^{43,44}$ who studied the tribological properties of steel composites reinforced with various volume fractions of the $\mathrm{TiB}_{2}$ particles. They indicated that the addition of $\mathrm{TiB}_{2}$ particles was very effective in improving the wear resistance and ductility of austenitic stainless steel. The addition of boron to the steel matrix has brought an additional improvement to the wear resistance. Studies have also proved a dependence of the friction coefficient on the sintering temperature. Higher sintering temperature reduced
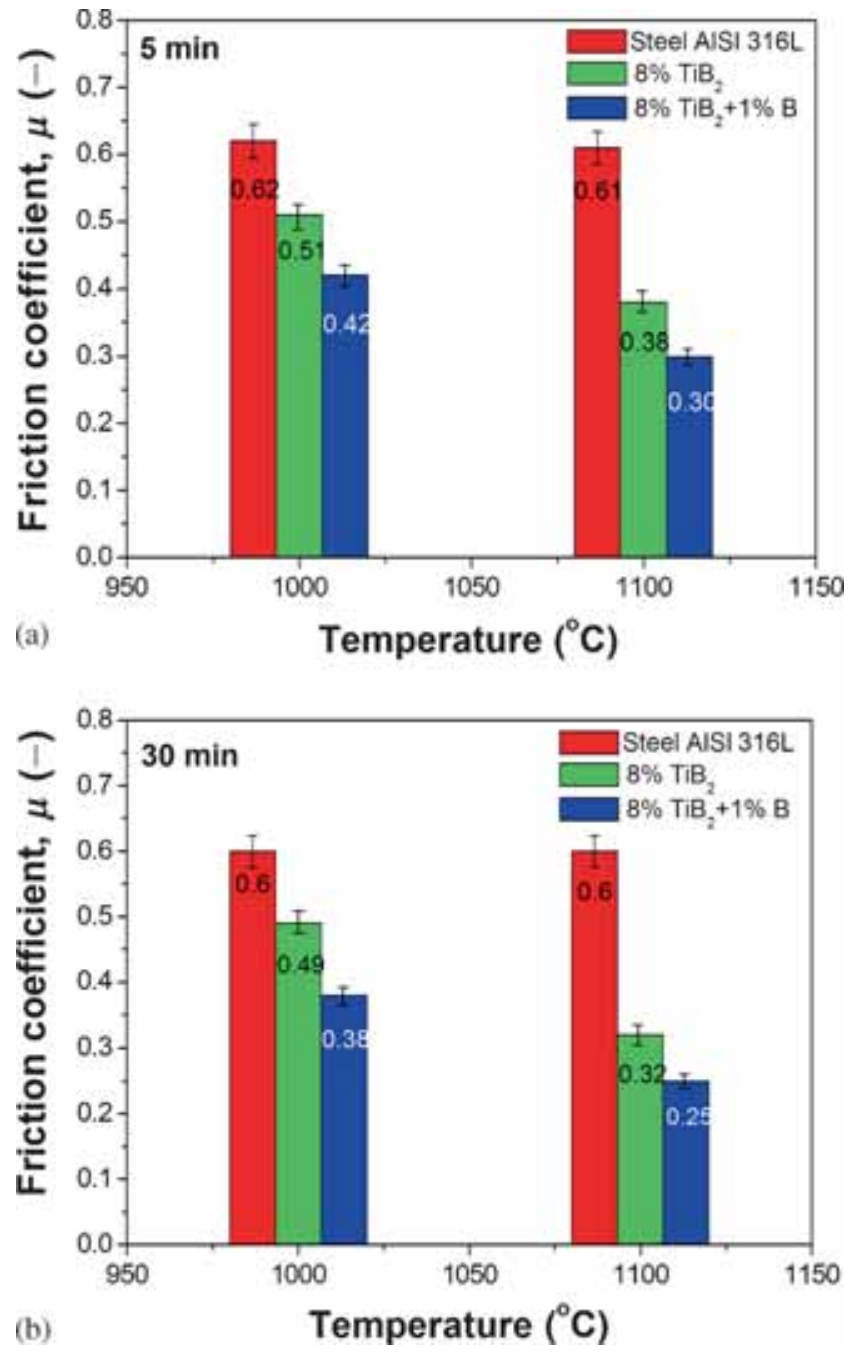

Figure 10. Friction coefficient values of materials sintered by SPS for: (a) $5 \mathrm{~min}$ and (b) $30 \mathrm{~min}$. 
the friction coefficient, reducing thereby also the wear rate of the material (figure 10). The best tribological properties were obtained in the materials sintered at $1100^{\circ} \mathrm{C}$ for $30 \mathrm{~min}$. The coefficients of friction and the specific wear rates of the steel$8 \% \mathrm{TiB}_{2}$ and steel-8\% $\mathrm{TiB}_{2}-1 \% \mathrm{~B}$ composites determined in tests carried out at room temperature were $\mu=0.32$ and 0.25 and $W_{V \text { (disc) }}=221.25$ and $207.78 \times 10^{-6} \mathrm{~mm}^{3}$ $\mathrm{N}^{-1} \mathrm{~m}^{-1}$, respectively. The homogeneous distribution of $\mathrm{TiB}_{2}$ and the presence of complex borides are favourable for the improvement of wear resistance. The next factor can be strong interfacial bonding obtained in composites at a temperature of $1100^{\circ} \mathrm{C}$. These materials are characterized by the highest level of consolidation. In the case of steel- $8 \% \mathrm{TiB}_{2}-$ $1 \% \mathrm{~B}$ composites, the reduction in the coefficient of friction and wear rate can also be achieved by higher amount of complex borides present in the composite microstructure.

Additionally, by the ball-on-disc method, the effect of test temperature on the tribological properties of composites was examined (figure 12). Tests carried out at elevated temperatures $\left(600\right.$ and $\left.800^{\circ} \mathrm{C}\right)$ showed the reduced abrasion resistance. The test temperature of $600^{\circ} \mathrm{C}$ definitely deteriorated the friction coefficient and doubled the wear compared to the results obtained at room temperature. The coefficient of friction and the specific wear rate of the steel-8\% $\mathrm{TiB}_{2}$ composite and steel-8\% $\mathrm{TiB}_{2}-1 \% \mathrm{~B}$ composite determined at a temperature of $600^{\circ} \mathrm{C}$ were $\mu=0.41$ and 0.40 and $W_{V(\text { disc })}=$ 485 and $405 \times 10^{-6} \mathrm{~mm}^{3} \mathrm{~N}^{-1} \mathrm{~m}^{-1}$, respectively. Raising the test temperature to $800^{\circ} \mathrm{C}$ reduced the abrasive wear resistance of the composite. The values of the friction coefficient determined at $800^{\circ} \mathrm{C}$ were similar for both composites and comprised in the range of $0.46-0.49$. The specific wear rate approached the value of $526-585 \times 10^{-6} \mathrm{~mm}^{3} \mathrm{~N}^{-1} \mathrm{~m}^{-1}$.

The reduced resistance to abrasion at elevated temperatures (figure 12) may be associated with the processes of oxidation. The oxidation of the composites has a significant effect on the wear rate. ${ }^{45}$ Degnan et $a l^{46}$ showed that
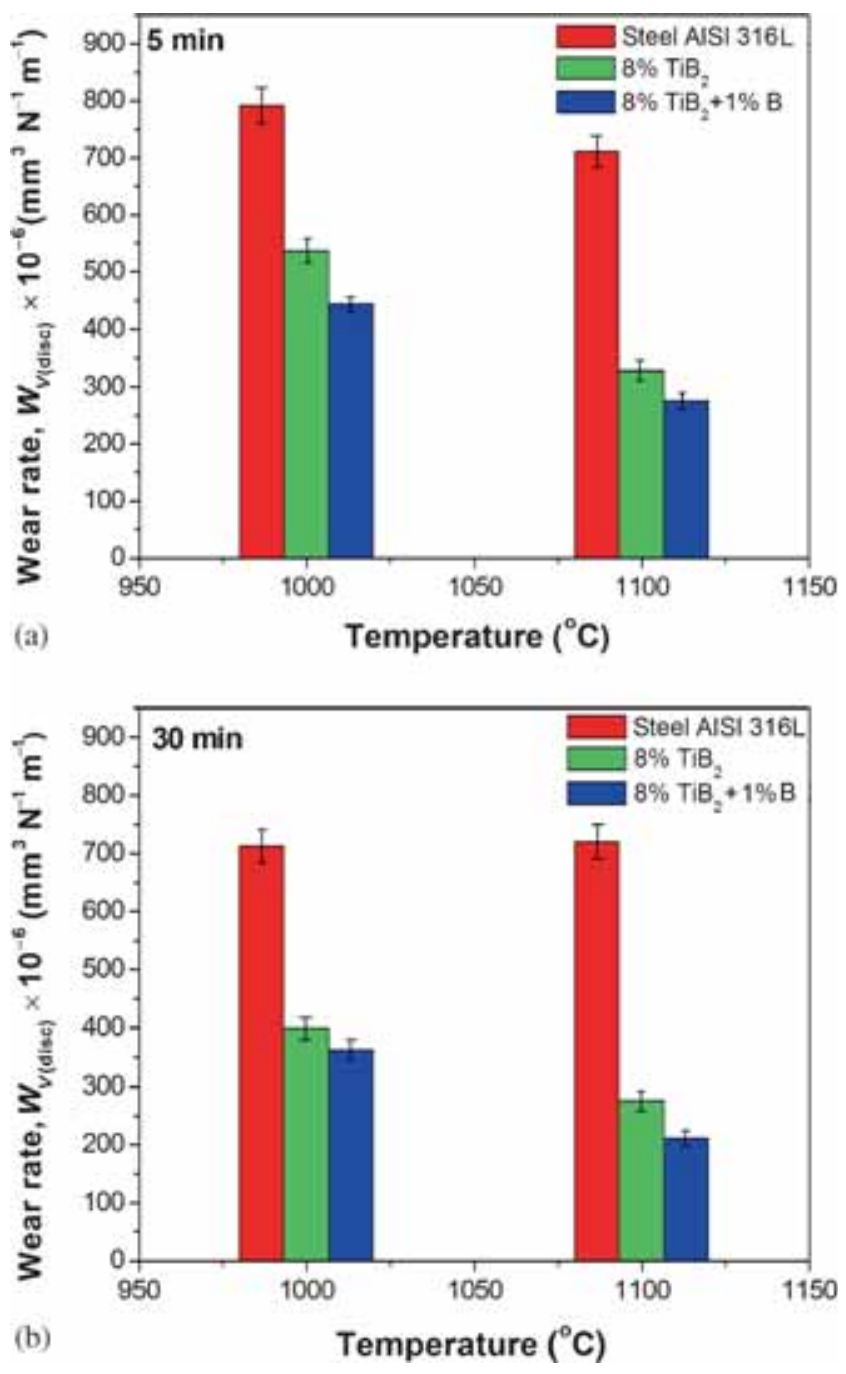

Figure 11. Wear rate values of materials sintered by SPS for: (a) $5 \mathrm{~min}$ and (b) $30 \mathrm{~min}$.
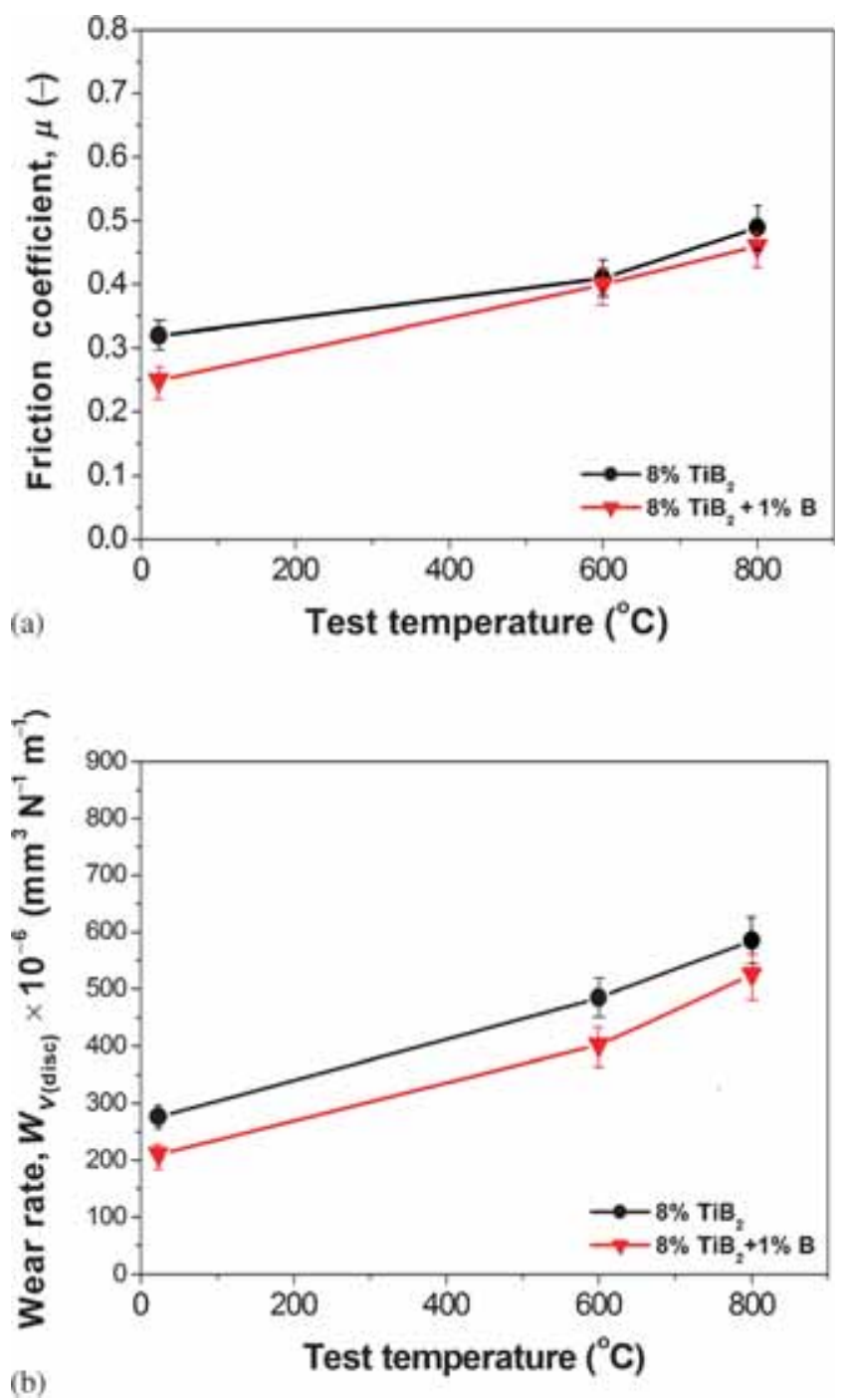

Figure 12. Effect of the wear test temperature on the (a) friction coefficient and (b) wear rates. 
increasing the test temperature has led to increased oxide production, making the oxide layers grow in thickness. The nature of the oxides formed is dependent on the temperature generated at the wear interface. According to literature, ${ }^{47,48}$ three iron oxides can be formed on the surface of steelmatrix composites. In sequence, the $\mathrm{Fe}_{2} \mathrm{O}_{3}$ is the oxide formed at lowest temperatures, followed by $\mathrm{Fe}_{3} \mathrm{O}_{4}$ which forms in the temperature range between 200 and $570^{\circ} \mathrm{C}$, and finally $\mathrm{FeO}$ which forms at temperatures above $600^{\circ} \mathrm{C}$. Moreover, it has been found that on the surface of the austenitic stainless steel at elevated temperature can develop chromium oxides $\left(\mathrm{Cr}_{2} \mathrm{O}_{3}\right)$ and complex oxides such as $\mathrm{FeCr}_{2} \mathrm{O}_{4}$ or $(\mathrm{Fe}$, $\mathrm{Ni}, \mathrm{Cr}) \mathrm{O}_{4} \cdot{ }^{48,49}$

\section{Conclusions}

1. The time and temperature of the SPS process have a significant impact on the properties and microstructure of the examined composites. Composites based on the austenitic stainless steel sintered by SPS at $1100^{\circ} \mathrm{C}$ have a very high density.

2. Young's modulus, compression strength and wear resistance of sintered composites were observed to increase with the increase of sintering temperature. Longer sintering time $(30 \mathrm{~min})$ also substantially improved the density and microhardness.

3. The addition of boron to the steel matrix improves the properties of composites (Young's modulus and wear resistance). High Young's modulus of $229 \pm 4 \mathrm{GPa}$ and microhardness of $465 \pm 18$ HV0.3 in combination with a compression strength of $1055 \pm 32 \mathrm{MPa}$ and high wear resistance was achieved for steel- $8 \% \mathrm{TiB}_{2}-1 \% \mathrm{~B}$ composites sintered at $1100^{\circ} \mathrm{C}$ for $30 \mathrm{~min}$.

4. Examinations of the composite matrix microstructure have revealed the presence of new phases in the form of complex borides: $\mathrm{BCr}_{0.2} \mathrm{Fe}_{1.8}$ and $(\mathrm{Cr}, \mathrm{Fe}, \mathrm{Mo}, \mathrm{Ni}$, $\mathrm{Ti})_{3} \mathrm{~B}_{2}$. The presence of boron in the steel matrix has an influence on the increased number of complex borides and their size.

\section{Acknowledgement}

This study was performed under statutory funds of Faculty of Mathematics, Physics and Technical Science, Pedagogical University in Krakow. We thank Professor Lucyna Jaworska (Institute of Advanced Manufacturing Technology in Krakow) for help in SPS process, Tomasz Tokarski, Ph.D. (AGH University of Science and Technology, Krakow), and Sonia Boczkal, Ph.D. (Institute of Non-Ferrous Metals in Gliwice, Light Metals Division Skawina), for help with the SEM and TEM investigations.

\section{References}

1. Novak C J, Peckner D and Bernstein I M editors 1977 Handbook of stainless steels (New York: McGraw-Hill)
2. Clyne T W and Withers P J editors 1993 An introduction to metal matrix composites (Cambridge: Cambridge University Press)

3. Sulima I, Klimczyk P and Malczewski P 2014 Acta Metall. Sin. (Engl. Lett.) 27112

4. Srivastava A K and Das K 2008 Mater. Lett. 623947

5. Patankar S N and Tan M J 2000 Powder Metall. 43350

6. Velasco F, Anton N, Torralba J M and Ruiz-Prieto J M 1997 Mater. Sci. Technol. 13847

7. Vardavoullus M, Jeandin M, Velasco F and Torralba J M 1996 Tribol. Int. 29499

8. Farid A, Guo S, Cui F, Feng P and Lin T 2007 Mater. Lett. 61 189

9. Sulima I, Jaworska L and Figiel P 2014 Arch. Metall. Mater. 59205

10. Pandya S, Ramakrishna K S, Annamalai A R and Upadhyaya A 2012 Mater. Sci. Eng. A556 271

11. German R M 1994 Powder metallurgy science (Princeton, NJ, USA: Metal Powder Industries Federation) 2nd edn, p 21

12. Zhaohui Z, Fuch W, Lin W, Shukui L and Osamu S 2008 Mater. Lett. 623987

13. Tokita M 2000 Sci. Technol. 3251

14. Kurgan N 2014 Mater. Des. 55235

15. Kazior J, Molinari A, Pieczonka T and Straffelini G 1998 Mater. Eng. 3335

16. Panda S S, Singh V, Upadhyaya A and Agrawal D 2006 Scr. Mater. $\mathbf{5 4} 2179$

17. Molinari A, Kazior J, Marchetti F, Cantieri R, Cristofolini A and Tiziani A 1994 Powder Metall. 37115

18. Molinari A, Straffelini G, Pieczonka T and Kazior J 1998 Int. J. Powder Metall. 3421

19. Almathami A and Brochu M 2010 J. Mater. Proc. Technol. 210 2119

20. Madan D S and German R M 1986 Mod. Dev. Powder Metall. 15441

21. Skałon M and Kazior J 2012 Arch. Metall. Mater. 57789

22. Molinari A, Menapace C, Kazior J and Pieczonka T 2007 Mater. Sci. 534-536 553

23. Madan D S and German R M 1989 Adv. Powder Metall. 1147

24. Molinari A, Kazior J and Straffelini G 1995 Mater. Charact. 34271

25. Karwan-Baczewska J 2011 Arch. Metall. Mater. 56789

26. Tojal C, Gómez-Acebo T and Castro F 2007 Mater. Sci. Forum 534-536 661

27. Bakan H I, Heaney D and German R M 2001 Powder Metall. 44235

28. Pellizzari M, Fedrizzi A and Zadra M 2011 Mater. Des. 32 1796

29. Dybkov V, Lengauer W and Barmak K J 2005 J. Alloys Compd. 398113

30. Molinari A Straffelini G, Kazior J and Pieczonka T 1996 Adv. Powder Metall. Part Mater. 512

31. Gierl Ch, Mohsin I U and Danninger H 2008 Powder Metall. Prog. 8135

32. Cabral-Miramontes J A, Barceinas-Sánchez J D O, AlmerayaCalderón F, Martinez-Villafaňe A and Chacón-Nava J G 2010 J. Mater. Eng. Perform. 19880 
33. Yilmaz R and Ekici M R 2008 J. Achieve. Mater. Manuf. Eng. 3123

34. Karwan-Baczewska J 2015 Arch. Metall. Mater. 6041

35. Abenojar J, Esteban D, Martinez M A and Velasco F 2007 Mater. Sci. Forum 534-536 733

36. Karwan-Baczewska J and Rosso M 2001 Powder Metall. 44 221

37. Tanaka K and Saito T 1999 J. Phase Equilibria 20207

38. Bacon D H and Edwards L 2012 Int. J. Fatigue 4839

39. Nahme H, Lach E and Tarrant A 2008 J. Mater. Sci. 44463

40. Zheng R, Hao X, Yuan Y, Wang Z, Ameyama K and Ma Ch 2013 J. Alloys Compd. 576291

41. Zhang Z H, Shen X B, Wang F Ch, Lee S K, Fan Q B and Cao M S 2012 Scr. Mater. 66167
42. Saheb N, Iqbal Z, Khalil A, Hakeem A S, Aqeeli N A, Laoui T, Al-Qutub A and Kirchner R 2012 J. Nanomater. Article ID 983470 doi: 10.1155/2012/983470

43. Tjong S C and Lau K C 1999 Mater. Lett. 4153

44. Tjong S C and Lau K C 2000 Compos. Sci. Technol. 601141

45. Mousavi Abarghouie S M R and Seyed Reihani S M $2010 \mathrm{~J}$. Alloys Compd. $\mathbf{5 0 1} 326$

46. Degnan C C, Shipway P H and Wood J V 2001 Wear 251 1444

47. Sullivan J L and Athwal S S 1983 Tribol. Int. 16123

48. Wang C J and Li C C 2004 Oxid. Met. 61485

49. Shariff N A, Jalar A, Sahri M I and Othman N K 2014 Sains Malays. 431069 